\title{
DATING PICTOGRAPHS WITH RADIOCARBON
}

\author{
WAYNE ILGER, ${ }^{1}$ MARIAN HYMAN, ${ }^{1}$ JOHN SOUTHON ${ }^{2}$ and MARVIN ROWE
}

\begin{abstract}
We report here progress on our technique for ${ }^{14} \mathrm{C}$ dating pictographs. We use low-temperature oxygen plasmas coupled with high-vacuum techniques to selectively remove carbon-containing material in the paints without contamination from rock substrates or accretions. We dated $>16$ pictograph samples that generally agree with ages expected on the basis of archaeological inference. We have shown that carbonate and calcium oxalate decomposition does not occur during our procedure; little mass fractionation is produced. We also used the technique on samples of known ${ }^{14} \mathrm{C}$ activity. In each case our results agree with previously determined ages of archaeological charcoal samples. Two samples of the standard Third International Radiocarbon Intercomparison wood yielded ages in near accord with the accepted value. We used ${ }^{14} \mathrm{C}$-free samples to establish that the method and apparatus do not have a significant live carbon background. Each of these determinations supports our conclusion that the technique has the potential of producing accurate and reliable ages. However, background organic material in the basal rocks and accretions can be troublesome, often completely negating the dates obtained.
\end{abstract}

\section{INTRODUCTION}

Researchers around the world have begun to date pictographs directly (van der Merwe, Sealy and Yates 1987; Loy et al. 1990; McDonald et al. 1990; Russ et al. 1990, 1991; Valladas, Cachier and Arnold 1990; Clottes, Courtin and Valladas 1992; David 1992; Farrell and Burton 1992; Geib and Fairley 1992; Russ, Hyman and Rowe 1992; Valladas et al. 1992; Watchman and Cole 1993; Chaffee, Hyman and Rowe 1993, 1994 a, b; Watchman 1993; Chaffee et al. 1994 a, b). In the past, lack of direct chronometric methods made it difficult to relate these pictographs to other archaeological artifacts and, thus, to known cultural sequences. Consequently, rock art was relegated to a marginal position with respect to mainstream archaeology. With the advent of direct ${ }^{14} \mathrm{C}$ dating using accelerator mass spectrometry (AMS), that situation is changing. We present here an update on our plasmachemical extraction technique for ${ }^{14} \mathrm{C}$ dating of pictographs. We obtained $16{ }^{14} \mathrm{C}$ ages that generally agree with dates inferred from archaeology. To test the method, we also determined the ${ }^{14} \mathrm{C}$ in samples of known activity: ${ }^{14} \mathrm{C}$-free albertite, a pyrobitumen; ${ }^{14} \mathrm{C}$-free wood; charcoal of previously determined ages; and previously-dated Third International Radiocarbon Intercomparison (TIRI) wood. In virtually every case, the measured values agree with those reported earlier. We used charcoal and collagen to examine mass fractionation; both indicate that this effect is minimal.

Prehistoric paint pigments are usually inorganic, primarily iron and manganese oxides. To facilitate attachment of the pigments to the rock wall, an organic binding medium or vehicle was often used. For example, DNA phylogenetic analysis of two Pecos River-style pictographs showed that mammalian (ungulate) organic matter (Artiodactyla) was incorporated in the paints (Reese et al. 1995). It is the total organic binder we wish to date, not necessarily restricted to the DNA-identified material. But the organic binder material must be extracted from a sample that contains a portion of the rock substrate along with the surface accretion. In many regions, the substrate is limestone $\left(\mathrm{CaCO}_{3}\right)$. Potentially, the largest contamination would be from decomposition of the inorganic carbon in the rock substrate and in calcite $\left(\mathrm{CaCO}_{3}\right)$ and whewellite (calcium oxalate, $\mathrm{CaC}_{2} \mathrm{O}_{4} \cdot \mathrm{H}_{2} \mathrm{O}$ ) accretions that occur on and below the pictographs. However, we have demonstrated that this does not occur with our method (Chaffee, Hyman and Rowe 1993). Inherent organic matter in the basal rock and accretions is often a serious problem as it is when dating charcoal. Although rarer than inorganic pigments in the archaeological record, charcoal was also used as pigment. It has been dated in many

\footnotetext{
${ }^{1}$ Department of Chemistry, Texas A \& M University, College Station, Texas 77843-3255 USA

${ }^{2}$ Center for Accelerator Mass Spectrometry, Lawrence Livermore National Laboratory, Livermore, California 94551-9900 USA
} 
laboratories including our own (van der Merwe, Sealy and Yates 1987; McDonald et al. 1990; Valladas, Cachier and Arnold 1990; Clottes, Courtin and Valladas 1992; David 1992; Farrell and Burton 1992; Geib and Fairley 1992; Valladas et al. 1992; Chaffee et al. 1994a).

Our approach to dating pictographs is different from all others. Lack of specificity in oxidizing organic material is both the main advantage of the technique, as well as a significant disadvantage, and permits us to date pictographs presently undatable by any other technique. We depend neither on the presence of charcoal nor other visible organic materials, such as plant remains used as a brush. We extract whatever organic material may be present in the paint (added as binder and/or vehicle) but we do not know the material being dated.

\section{METhodS}

We use a radio frequency $(\mathrm{RF})$ generated low-temperature $\left(<175^{\circ} \mathrm{C}\right)$, low-pressure $(\sim 1$ torr $)$ oxygenplasma, coupled with high-vacuum equipment to remove the organic matter in the paint, while leaving the substrate rock and carbonate/oxalate accretions intact. The gaseous products are collected by freezing in a liquid nitrogen $\left(\mathrm{LN}_{2}\right)$ cold finger. The organic component is analyzed by AMS, enabling these pictographs to be ${ }^{14} \mathrm{C}$ dated. We described our plasma-chemical apparatus previously and will not repeat it in detail here (Russ et al. 1991; Russ, Hyman and Rowe 1992; Chaffee, Hyman and Rowe 1993). We emphasize only that all pumping is accomplished with oil-free pumps. We routinely perform leak tests to ensure high-vacuum integrity. We showed that ultra-pure (99.999\%) bottled $\mathrm{O}_{2}$ and $\mathrm{Ar}$ are free $(<0.5 \mu \mathrm{g} \mathrm{C})$ of organic material and $\mathrm{CO}_{2}$ after they have passed through $\mathrm{LN}_{2}$ traps. Copper-gasketed, blank flanges are used as entry ports for sample introduction into the chamber. We clean the sample and chamber surfaces with $\mathrm{Ar}$ and $\mathrm{O}$ plasmas until the background $\mathrm{CO}_{2}$ collected is $\sim 0.5 \mu \mathrm{g} \mathrm{C}$, which is less than the AMS background.

Neither the chemicals, $\mathrm{CaCO}_{3}, \mathrm{MgCO}_{3}, \mathrm{CaC}_{2} \mathrm{O}_{4} \cdot \mathrm{H}_{2} \mathrm{O}$, nor natural limestone decompose into $\mathrm{CO}_{2}$ during the plasma operation (Chaffee, Hyman and Rowe 1993). This is critical because, upon decomposition, all of these would produce relatively large amounts of ${ }^{14} \mathrm{C}$-free $\mathrm{CO}_{2}$. All would yield carbon of unknown age and all would have a devastating effect on a ${ }^{14} \mathrm{C}$ date.

We examined the mass fractionation in $\mathrm{CO}_{2}$ produced from plasma oxidation of a collagen sample and found $<1.5 \%$ change from the average in $\delta^{13} \mathrm{C}$. A series of $\delta^{13} \mathrm{C}$ values measured on the collagen sample were $-19.98,-19.93,-20.91,-18.57$ and -20.46 . We reported previously that essentially no mass fractionation occurred in $\mathrm{CO}_{2}$ produced from plasma oxidation of a sample of charcoal; the maximum change was only $0.16 \%$ (Russ, Hyman and Rowe 1992).

\section{RESUlTS}

We subjected several samples of known ${ }^{14} \mathrm{C}$ content, both recent and ${ }^{14} \mathrm{C}$-free, to our plasma treatment; some results were reported earlier (Chaffee, Hyman and Rowe 1993) and others here. The ${ }^{14} \mathrm{C}$ ages from plasma chemical extraction agree well with the previously determined ${ }^{14} \mathrm{C}$ content (Table 1). The two TIRI wood samples showed the greatest difference. Our first TIRI aliquot was scrapings ( $4.8 \mathrm{mg}$ total) from all the exposed rings of a large piece of $\operatorname{wood}(\sim 2 \mathrm{~cm} \times 4 \mathrm{~cm} \times 9 \mathrm{~cm})$. The wood sample had been sent to us in a plastic bag and stored in our laboratory in the same bag. No pretreatment was given to the samples subjected to the plasma-chemical technique. The outer surface that we used as our sample could have been slightly contaminated with the plasticizer of the storage material. It is older, as would be expected if it were contaminated with $\sim 4 \mathrm{~g}$ of ${ }^{14} \mathrm{C}$-free carbon. The second TIRI sample, also small $(6.3 \mathrm{mg})$, was taken from the interior of the wood after splitting. This result agrees very well with the previously determined age of the sample, even without pre- 
TABLE 1. Current Status of Samples with Known Radiocarbon Content

\begin{tabular}{|c|c|c|c|}
\hline Sample & Lab no. & $\begin{array}{l}{ }^{14} \mathrm{C} \text { age } \\
\text { (yr BP) }\end{array}$ & Known ${ }^{14} \mathrm{C}$ \\
\hline \multicolumn{4}{|l|}{ Known age } \\
\hline & ETH-7165 & $3665 \pm 65$ & $3655 \pm 60$ \\
\hline Charcoal & AA-8357 & $3285 \pm 75$ & $3410 \pm 65$ \\
\hline Charcoal & AA-8358 & $3650 \pm 75$ & $3655 \pm 65$ \\
\hline \multirow[t]{2}{*}{ TIRI wood (Core sample B) } & CAMS-10554 & $4730 \pm 60^{*}$ & \\
\hline & CAMS-11432 & $4530 \pm 60 \dagger$ & \\
\hline Ring no. 10 & $\begin{array}{l}\text { CAMS- } 4527 \text { and } \\
\text { CAMS- } 4534\end{array}$ & & $4495 \pm 40 \ddagger$ \\
\hline \multirow[t]{2}{*}{ Ring no. 20} & CAMS- 4526 and & & $4450 \pm 35 \pm$ \\
\hline & CAMS-4533 & & \\
\hline \multirow[t]{3}{*}{ Ring no. 30} & CAMS-4525 and & & $4525 \pm 35 \ddagger$ \\
\hline & CAMS-4532 & & \\
\hline & Mean of six CAMS & measurements & $\begin{array}{l}4490 \pm 21 \\
4485 \S\end{array}$ \\
\hline \multicolumn{4}{|l|}{${ }^{14} C$-free carbon } \\
\hline Albertite & AA-8033 & $46,800 \pm 3100$ & $>40,000$ \\
\hline Albertite & AA-8241 & $37,600 \pm 1000$ & $>40,000$ \\
\hline Albertite & AA-9332 & $46,000 \pm 6000$ & $>40,000$ \\
\hline IAEA wood & CAMS-9648 & $>35,500$ & $>35,500$ \\
\hline $\begin{array}{l}\text { Axel Heiberg wood } \\
\text { (partially coalified) }\end{array}$ & CAMS-9649 & $>35,500$ & $>35,500$ \\
\hline \multicolumn{4}{|c|}{$\begin{array}{l}\text { Surface sample, see text. } \\
\text { †Interior sample, see text. } \\
\text { \$Run at the Center for Accelerator Mass Spectrometry (CAMS), Lawrence Livermore National Laboratory, } \\
\text { as part of their participation in TIRI. Each value is the mean of two determinations. } \\
\text { \$Preliminary canonical mean of determinations of TIRI } \\
\text { This range includes } 50 \% \text { of the reported measurements to TIRI. }\end{array}$} \\
\hline
\end{tabular}

treatment. When pristine, interior samples are unavailable, pretreatment is advised. In both cases, we ran the plasmas for short times ( $75 \mathrm{sec}$, generating $260 \mu \mathrm{g} \mathrm{C}$, that was split into two tubes, and $85 \mathrm{sec}$, generating $320 \mu \mathrm{g} \mathrm{C}$ ) to produce samples of carbon small enough to mimic pictograph sample sizes.

We chose albertite as a source of ${ }^{14} \mathrm{C}$-free carbon to check our technique for modern contamination. It is not the best material for this purpose because it often has residual ${ }^{14} \mathrm{C}$ contamination that is difficult to remove. However, the ages we obtained were satisfactory. Only the third sample, dated to $37,600 \pm 1000 \mathrm{BP}$, showed any sign of ${ }^{14} \mathrm{C}$, indicating a contamination of $0.9 \%$ modern (pMC) (1950) carbon. We later analyzed higher-quality ${ }^{14} \mathrm{C}$-free samples, IAEA wood and partially coalified Axel Heiberg wood, which were at or below AMS background levels in ${ }^{14} \mathrm{C}$. The ${ }^{14} \mathrm{C}$-free samples measured show that it is possible to extract carbon with the plasma-chemical technique without significant modern contamination.

We have added several ${ }^{14} \mathrm{C}$ dates on pictographs to the three in our previous report (Russ, Hyman and Rowe 1992). Some have been published elsewhere (Chaffee, Hyman and Rowe 1993, 1994a, 1994b; Chaffee et al. 1994a,b); others appear here for the first time. Table 2 lists pictograph ${ }^{14} \mathrm{C}$ dates from our laboratory; Table 3 lists experimental conditions used for the oxygen plasma-chem- 
TABLE 2. Texas A\&M Pictograph Dates

\begin{tabular}{|c|c|c|c|}
\hline Site/Pictograph no. & $\begin{array}{c}{ }^{14} \mathrm{C} \text { date } \\
\text { (yr BP) }\end{array}$ & Lab no. & References \\
\hline $\begin{array}{l}\text { Pecos River, Texas } \\
41 \mathrm{VV75-1} \\
41 \mathrm{VV} 576-3 \mathrm{a} \\
41 \mathrm{VV} 576-1 \mathrm{a} \\
41 \mathrm{VV} 576-1 \mathrm{~b} \\
41 \mathrm{VV} 50-3 \mathrm{a} \\
41 \mathrm{VV} 50-3 a, 2 \sigma \mathrm{cal} B P \\
\text { Expected age }\end{array}$ & 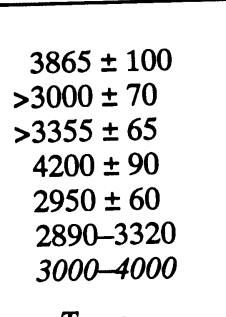 & $\begin{array}{l}\text { ETH-5909 } \\
\text { ETH-7047 } \\
\text { ETH-6962 } \\
\text { AA-7063 } \\
\text { AA-8699 }\end{array}$ & $\begin{array}{l}\text { Russ et al. }(1990) \\
\text { Russ, Hyman and Rowe (1992) } \\
\text { Russ, Hyman and Rowe (1992) } \\
\text { Chaffee, Hyman and Rowe (1993) }\end{array}$ \\
\hline $\begin{array}{l}\text { Red Monochrome, Lewis Can } \\
41 \mathrm{VV} 233-1 \\
41 \mathrm{VV} 233 \text { background } \\
41 \mathrm{VV} 233 \text { bkgd corrected } \\
41 \text { V } 233,2 \sigma \text { cal BP } \\
\text { Expected age }\end{array}$ & $\begin{array}{l}\text { yon, Texas } \\
1315 \pm 50 \\
1660 \pm 70 \\
1125 \pm 85^{*} \\
800-1260 \\
650-1350\end{array}$ & $\begin{array}{l}\text { AA-9270 } \\
\text { CAMS-11891 }\end{array}$ & Dillehay (1974); Turpin (1986a) \\
\hline 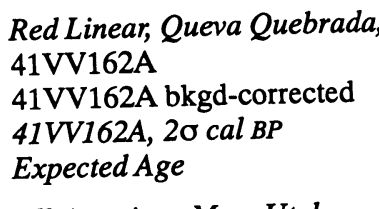 & $\begin{array}{l}\text { Texas } \\
1280 \pm 45 \\
1280 \pm 150 \dagger \\
950-1520 \\
1350-3000\end{array}$ & AA-10549 & Dillehay (1974); Turpin (1984) \\
\hline $\begin{array}{l}\text { All-American Man, Utah } \\
\text { 42SA1614-1a } \\
\text { 42SA1614-1b } \\
\text { Average } 1 a \text { and } 1 b \\
\text { Expected Age }\end{array}$ & $\begin{array}{l}753 \pm 57 \\
575 \pm 68 \\
675 \pm 46 \\
650-950\end{array}$ & $\begin{array}{l}\text { AA-8359 } \\
\text { AA-8361 }\end{array}$ & $\begin{array}{l}\text { Chaffee et al. }(1994 \mathrm{~b}) \\
\text { Chaffee et al. }(1994 \mathrm{~b}) \\
\text { Chaffee et al. }(1994 \mathrm{~b}) \\
\text { Chaffee et al. }(1994 \mathrm{~b}) \text {; } \\
\text { Chandler (1990) }\end{array}$ \\
\hline $\begin{array}{l}\text { White Bird Shelter, Utah } \\
\text { 42SA20615 }\end{array}$ & $2710 \pm 75 \ddagger$ & AA-9179 & Chaffee, Hyman and Rowe (1993) \\
\hline $\begin{array}{l}\text { Great Gallery, Horseshoe } \mathrm{Ca} \\
42 \mathrm{WN} 318-3 \mathrm{a}\end{array}$ & $\begin{array}{l}\text { nyon, Utah } \\
\quad 32,900 \pm 900 \S\end{array}$ & AA-8747 & Chaffee, Hyman and Rowe (1994a) \\
\hline $\begin{array}{l}\text { Elk Creek Cave, Montana } \\
24 \mathrm{BH} 501 \\
\text { Expected age }\end{array}$ & $\begin{array}{l}840 \pm 50 \\
850 \pm 50\end{array}$ & AA- 8843 & $\begin{array}{l}\text { Chaffee et al. (1994b) } \\
\text { Loendorf (1988) }\end{array}$ \\
\hline $\begin{array}{l}\text { Cueva del Ratón, Mexico } \\
2 \\
6 \\
\text { Background }\end{array}$ & $\begin{aligned} 295 & \pm 115^{*} \\
1325 & \pm 125^{*} \\
3490 & \pm 60\end{aligned}$ & $\begin{array}{l}\text { AA-9226 } \\
\text { AA-9234 } \\
\text { CAMS-14091 }\end{array}$ & \\
\hline $\begin{array}{l}\text { Mucubal 1, Opeleva Cave, A } \\
\text { Mucubal 1a } \\
\text { Mucubal 1, 20 cal BP } \\
\text { Mucubal 1b } \\
\text { Mucubal 1c }\end{array}$ & $\begin{array}{l}\text { ngola, Africa } \\
\qquad 2340 \pm 50 \# \\
2160-2650 \\
1880 \pm 100 \# \\
1900 \pm 60 \# \\
\end{array}$ & $\begin{array}{l}\text { CAMS-10891 } \\
\text { CAMS-11325 }\end{array}$ & \\
\hline
\end{tabular}

*See discussion in text.

†This sample had a $9 \%$ background carbon content that was not dated; discussed in text.

$\ddagger$ No background is available for this sample, so it should be regarded with extreme caution.

¥No background is avalable for the pictograph was in situ. $\S$ This sample was contaminated by kerosene, pros treated for removal of limestone and humic acids, $1 \mathrm{~b}$ and $1 \mathrm{c}$ were not. They \#These samples were aliquots. Mucubal in text. 
TABLE 3. Experimental Conditions for the Oxygen Plasma Extractions

\begin{tabular}{|c|c|c|c|c|}
\hline Sample & $\begin{array}{l}\text { Reaction } \\
\text { time (min) }\end{array}$ & $\begin{array}{l}\text { Power } \\
\text { (watts) }\end{array}$ & $\begin{array}{l}\text { Pressure } \\
\mathrm{O}_{2} \text { (torr) }\end{array}$ & $\begin{array}{c}\text { Extracted } \\
\text { carbon }(\mathrm{mg})\end{array}$ \\
\hline $\begin{array}{l}\text { Red Monochrome, Le } \\
41 \text { VV233-1 } \\
41 \text { VV233-2* }\end{array}$ & $\begin{array}{c}\text { is Canyon, } \mathrm{Te} \\
81 \\
82\end{array}$ & 100 & $\begin{array}{l}1.2 \\
1.2\end{array}$ & $\begin{array}{l}1.79 \\
0.66 \dagger\end{array}$ \\
\hline $\begin{array}{l}\text { Red Linear; Cueva } Q \\
\text { 41VV162A } \\
\text { 41VV162A* }\end{array}$ & $\begin{array}{c}\text { ebrada, Texas } \\
50 \\
55\end{array}$ & $\begin{array}{l}100 \\
100\end{array}$ & $\begin{array}{l}1.1 \\
1.0\end{array}$ & $\begin{array}{l}0.90 \\
0.08 \dagger\end{array}$ \\
\hline $\begin{array}{l}\text { Cueva del Ratón, Mex } \\
\text { Red pigment-6 } \\
\text { Background* }\end{array}$ & $\begin{array}{l}186 \\
180\end{array}$ & $\begin{array}{l}100 \\
100\end{array}$ & $\begin{array}{l}1.1 / 0.9 \ddagger \\
1.1\end{array}$ & $\begin{array}{l}0.87 \\
0.19 \dagger\end{array}$ \\
\hline $\begin{array}{l}\text { Mucubal, Opeleva Ca } \\
\text { 1a, charcoal pigment } \\
\text { 1b, charcoal pigment }\end{array}$ & $\begin{array}{c}\text { e, Angola } \\
9 \\
15\end{array}$ & $\begin{array}{l}50 \\
50\end{array}$ & $\begin{array}{l}0.9 \\
1.0\end{array}$ & $\begin{array}{l}0.17 \\
0.30\end{array}$ \\
\hline
\end{tabular}

\section{Discussion}

Our pictograph dates generally fall within the age range expected from archaeological inference (Table 2). Unfortunately, the constrained time intervals are too broad to permit evaluation of the detailed accuracy of the method. Some of these dates warrant further explanation here. We calculated calibrated ranges according to Stuiver and Reimer (1993).

\section{Lower Pecos River Region, Texas}

Four styles of prehistoric pictographs are recognized in the Lower Pecos River region: 1) Pecos River, dated between $2950 \pm 60$ and $4200 \pm 90 \mathrm{BP}$ (calibrated ages: at $1 \sigma, 2960-3240 \mathrm{cal} \mathrm{BP}$; at $2 \sigma$, 2890-3320 cal BP; and at $1 \sigma, 4550-4840 \mathrm{cal} \mathrm{BP}$; at $2 \sigma, 4320-4960 \mathrm{cal}$ BP, respectively; 2) Red Linear, younger than Pecos River, based on superposition, but otherwise with no established time frame (Greider 1966; Turpin 1984); 3) Red Monochrome, with figures sometimes carrying bows and arrows, which could place them between ca. $1350 \mathrm{yr}$ ago and historical times (Kelley 1950; Turpin 1986a); 4) Bold Line Geometric, again younger than Pecos River, but also not well dated in the archaeological record (Turpin 1986b). We discuss here recent attempts to date Red Linear- and Red Monochrome-styles.

\section{Red Linear Pictograph (41VV162A)}

We sampled a Red Linear pictograph panel at Cueva Quebrada, 41VV162A, ca. $4.5 \mathrm{~km}$ north of the confluence of the Rio Grande and Pecos Rivers. The shelter is high on the north wall of a small dry canyon. Three ${ }^{14} \mathrm{C}$ dates were previously determined on material from this shelter: $14,300,13,920$ and 12,280 BP (Valastro, Davis and Varela 1977). All were on wood charcoal associated with extinct fauna, and are not of value in interpreting the dates of the pictographs at this site, assuming the extant fauna have nothing to do with the pictographs.

The carbon extracted from the 41VV162A pictograph sample was dated at $1280 \pm 45 \mathrm{BP}$ (Table 2). As part of our routine procedure, we subject not only pictograph samples, but also samples of unpainted nearby rock, to the plasma treatment to ascertain the extent of organic contamination in 
the basal rock and the associated mineral accretions. We then measured the volume of $\mathrm{CO}_{2}$ produced from both types of sample. In this case, extraction of the organic carbon from unpainted limestone near the pictograph showed a contamination level of $9 \%$ of the amount of $\mathrm{CO}_{2}$ generated from the pictograph (Table 3). The source of contamination on the unpainted shelter wall is unknown. However, the $\delta^{13} \mathrm{C}$ of the unpainted limestone background $\mathrm{CO}_{2}$ was $-23.1 \%$. The processes that produce limestone result in a $\delta^{13} \mathrm{C}$ of $c a .0 \%$. Typical animal and vegetable organic material yields $\delta^{13} \mathrm{C}$ values of $c a$. -19 to $-25 \%$; those producing atmospheric $\mathrm{CO}_{2}$ result in a $\delta^{13} \mathrm{C}$ of $-7.8 \%$. The mass fractionation value of the background contamination on the unpainted limestone sample suggests it is contaminant organic carbon of unknown age. Most $\delta^{13} \mathrm{C}$ values of our pictograph samples are between -20 and $-26 \%$; that for the 41VV162A pictograph sample was $-20.2 \%$.

The pictographs most familiar to us, those in the Lower Pecos River region, are usually painted over a mineral accretionary layer. An ancient ${ }^{14} \mathrm{C}$-free surface could have been exposed 1) by intentional removal of the top layers to provide an improved base for painting, or 2) by natural spalling that would have had to have exfoliated shortly before the paint was applied. We have seen no indication of prepared surfaces in the Lower Pecos River region. Figure 1 shows a polished section where a pictograph was painted over clearly existing accretionary minerals. It is also unlikely that a significant fraction of pictographs was painted soon after natural spallation exposed an ancient surface. Thus, most pictographs in the Lower Pecos River region were probably painted on top of evolving, and thus relatively young surfaces formed in the last few millennia. This means that the outermost atomic layers of mineral accretion underlying the pigmented layer would be virtually the same age as the binder/vehicle mixed with the pigment. Deeper layers would reflect the growth time of the accretion and would thus be older. Sometime after a pictograph is painted, a new accretion layer forms over the painting. In practice, the organic binder/vehicle that we extract from a pictograph sample is a composite of pictograph organic matter and contamination organic matter in overlying accretions. The latter presumably was deposited during an interval beginning before the application of the paint (the accretion layer beneath the pictograph) and continuing to modern time (the accretion layer over

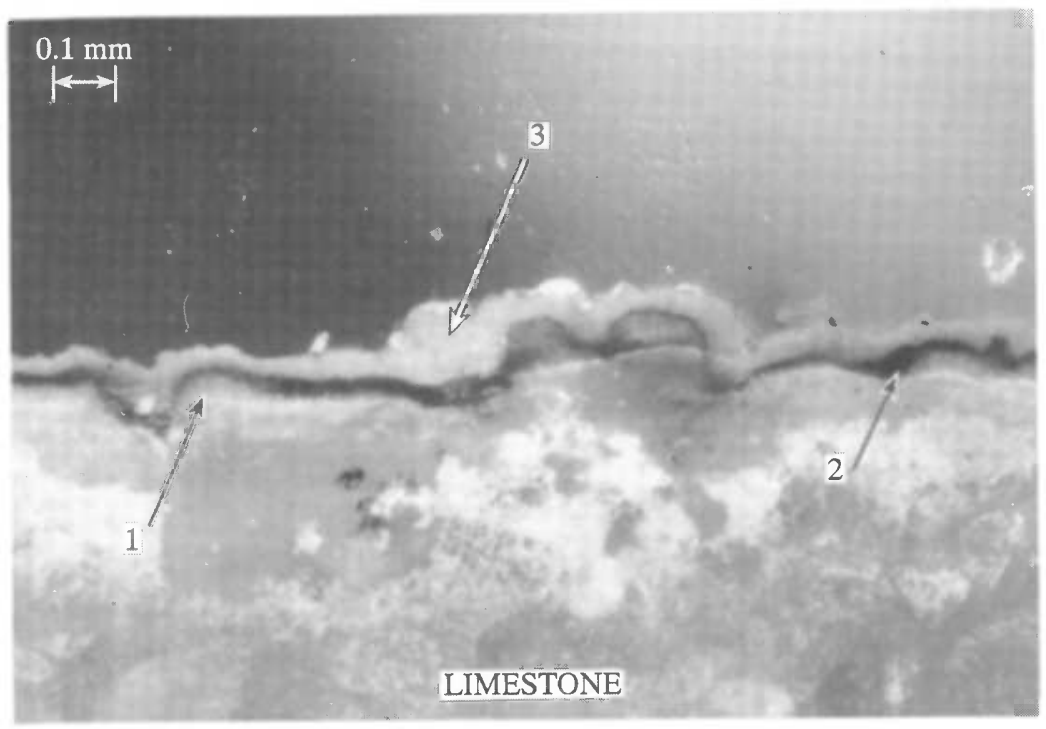

Fig. 1. Polished section of a pictograph from 41VV75 showing 1) the underlying accretion layer upon which the paint was applied; 2) a red pigment layer; 3 ) an outer accretion layer that grew over the pictograph after it was painted. 
the pictograph). If we assume that as they form, accretion surface layers continuously accumulate and uniformly incorporate ambient live carbon, then the depth of a given layer is directly proportional to the ${ }^{14} \mathrm{C}$ age of the contamination incorporated in that layer. Thus contamination carbon observed in the unpainted limestone by the plasma-chemical treatment would be a time-averaged composite of the surficial layers (incorporating ambient carbon at the time of mineral formation) that were sampled. Without testing for background and correcting for this effect when the background is significant, a ${ }^{14} \mathrm{C}$ age of a pictograph means little. We are assuming in the background corrections here that the background contamination is uniform. More work is needed to confirm or negate this assumption.

We corrected for the accretion contamination using the following equation (Mook and Waterbolk 1985)

$$
X=\left(a-a_{s}\right) /\left(a_{c}-a_{s}\right) \quad \text { so that } \quad a_{s}=\left(X a_{c}-a\right) /(X-1)
$$

where $X$ is the fractional contamination of the sample, $a$ is the fractional ${ }^{14} \mathrm{C}$ activity of the sample, $a_{s}$ is the fractional ${ }^{14} \mathrm{C}$ activity of the assumed "true" age of the sample, and $a_{c}$ is the fractional ${ }^{14} \mathrm{C}$ activity of the contamination. The fractional contamination of the sample, $X$, was determined by pressure and volume measurements. For sample 41VV162A, we scraped off $<0.5 \mathrm{~mm}$ of the painted surface, and thus expect contamination to be relatively recent. We did not date the background contamination for this pictograph. Instead, we took the older of the two dated background samples from the Lower Pecos River region, i.e., $2900 \pm 60$ BP at Shelter 41VV78, as the contamination age. This was chosen to give the larger uncertainty on the estimate. After making these substitutions in Equation (1), the corrected lower limit age became $1135 \mathrm{BP}$. Considering the effect of the background and the AMS uncertainty on the uncorrected date, our estimate of the pictograph age is between 1135 and $1415 \mathrm{BP}$. The older age arises from assuming the background carbon was modern. The measured age of $1280 \mathrm{BP}$ is near the midpoint of this range; thus the date may best be represented as $1280 \mathrm{BP}$ (at l $\sigma, 970-1310 \mathrm{cal} \mathrm{BP}$; at $2 \sigma, 920-1520 \mathrm{cal} \mathrm{BP}$ ) with an uncertainty that includes the AMS counting uncertainty, $\pm 45 \mathrm{yr}$, as well as that introduced by the contamination, $\pm 145 \mathrm{yr}$. Propagation of these uncertainties leads to a total uncertainty of $\pm 150 \mathrm{yr}(l \sigma)$. The effect of the organic contamination in the substrate rock and accretions, based on the above assumptions, is to increase the uncertainty given by AMS counting statistics alone by a factor of just over three.

Red Linear pictographs are younger than Pecos River style pictographs based on superposition (Turpin 1984), and thus are estimated to be < ca. 3000 BP. Greider (1966) interpreted the scene at $41 \mathrm{VV} 162 \mathrm{~A}$ to be 17 running animals, possibly deer or bison. Turpin (1984) proposed that the pictograph depicts bison being herded toward a crack in the wall, representing the edge of a cliff. The scene would then portray jump-hunting, with bison chased off a precipice and killed by the fall or the hunters. Another possible Red Linear bison is depicted at Shelter 41 VV612 (Turpin 1984). Bison were known to be abundant in the Lower Pecos River area during only three periods (Dillehay 1974: 181): Period I, "10,000 to 6000-5000 B.C."; Period II, "2500 B.C. to A.D. 500"; Period III, “A.D. 1200-1300 to 1550". Dillehay's dates are uncalibrated. The background-corrected age of this pictograph, $1280 \pm 150 \mathrm{BP}$, overlaps within $2 \sigma$ with the more recent end of Dillehay's Period II. Clearly, additional dates will be required to validate this one result.

\section{Red Monochrome Pictograph (41VV233)}

This Red Monochrome pictograph is located at the base of Lewis Canyon on the east bank of the Pecos River. Just above Lewis Canyon is a flat $4000 \mathrm{~m}^{2}$ limestone bed noted for its many petroglyphs (Site 41VV236, shown in Kirkland and Newcomb 1967). The Lower Pecos River area has 
hundreds of pictograph sites, but relatively few petroglyphs. Drainage from the area that includes the petroglyph field empties over a small cliff $c a .100 \mathrm{~m}$ to the southwest of the main petroglyph site, where it has eroded a circular shelter (41VV233). The center of the shelter is a deep sink hole ca. $7 \mathrm{~m}$ wide, making this site unusually humid for the arid Lower Pecos River region. Figure 2 shows a Red Monochrome pictograph at 41VV233 (Turpin 1986a) that resembles an anthropomorphic petroglyph (Fig. 3) from the adjacent petroglyph field. Neither the pictographs nor the petroglyphs at Lewis Canyon have been dated previously.

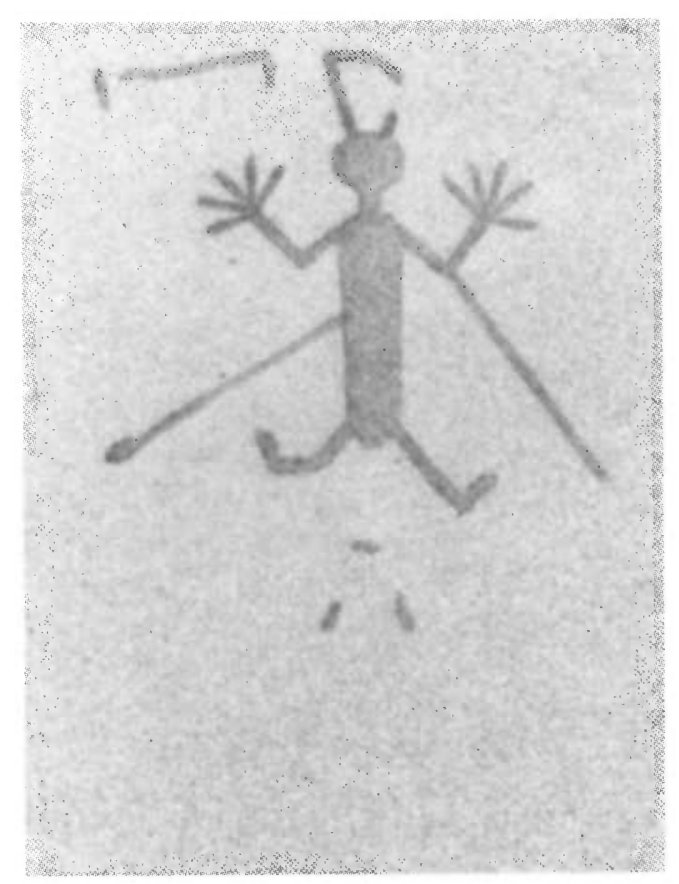

Fig. 2. Kirkland's drawing (Kirkland and Newcomb 1967) of the anthropomorphic Red Monochrome pictograph $41 \mathrm{VV} 233$. The image is $c a .85 \mathrm{~cm}$ long from the bottom of the left foot to the top of the headdress.

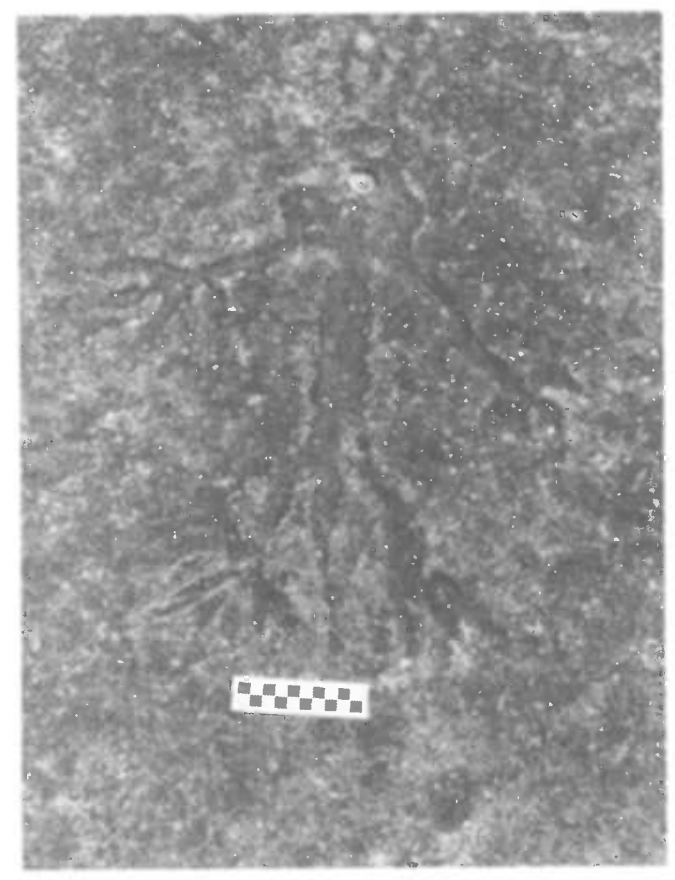

Fig. 3. Close-up photograph of the anthropomorphic petroglyph at $41 \mathrm{VV} 236$ that is similar to the pictograph at Red Monochrome Shelter 41VV233, Lewis Canyon, Texas, which we dated. The image is $c a .50 \mathrm{~cm}$ long.

We collected milligram-sized samples from multiple areas of the pictograph and the nearby unpainted limestone rock-accretion combination. As usual, we measured the volumes of plasma-chemically extracted $\mathrm{CO}_{2}$ for the unpainted limestone/accretion background and the pictograph samples. The unpainted sample yielded an amount of $\mathrm{CO}_{2}$ that was $37 \%$ of the sample's $\mathrm{CO}_{2}$ (Table 3). Thus, a serious source of uncertainty beyond AMS background correction and counting statistics is introduced by the background contamination organic carbon in the unpainted rock-accretion sample. We estimate the analytical uncertainty in the measurement of the fraction of background in the pictograph sample is $c a . \pm 15 \%$; this is probably less important than whether the background is homogeneously distributed. The amount of background $\mathrm{CO}_{2}$ was large enough to be dated, alleviating the need to make any assumption regarding its age. This unpainted sample yielded an age of $1660 \pm 70$ BP. $\mathrm{A}^{14} \mathrm{C}$ age of $1315 \pm 50 \mathrm{BP}$ was obtained for pictograph 41VV233-1. Combining the fraction contamination with the ${ }^{14} \mathrm{C}$ activities from the AMS laboratories allows us to calculate the backgroundcorrected "true" age of a sample, and the propagated variance $\left(\operatorname{var}\left(a_{s}\right)\right)$ of the fractional ${ }^{14} \mathrm{C}$ activity $\left(a_{s}\right)$ of the assumed "true" age is calculated using Equation (1) and the following result (Equation 2): 


$$
\operatorname{var}\left(a_{s}\right)=\left[\frac{\delta}{\delta X}\left(\frac{X a_{c}-a}{X-1}\right)\right]^{2} \operatorname{var}(X)+\left[\frac{\delta}{\delta a_{c}}\left(\frac{X a_{c}-a}{X-1}\right)\right]^{2} \operatorname{var}\left(a_{c}\right)+\left[\frac{\delta}{\delta a}\left(\frac{X a_{c}-a}{X-1}\right)\right]^{2} \operatorname{var}(a)
$$

to give

$$
\operatorname{var}\left(a_{s}\right)=\left[\frac{\left(a-a_{c}\right)}{(X-1)^{2}}\right] \operatorname{var}(X)+\left[\frac{X}{(X-1)}\right]^{2} \operatorname{var}\left(a_{c}\right)+\left[\frac{-1}{(X-1)}\right]^{2} \operatorname{var}(a)
$$

Substitution of the proper values into Equations 1 and 3 yields a background-corrected age of 1125 $\pm 85 \mathrm{BP}$ (at $1 \sigma, 930-1170 \mathrm{cal} \mathrm{BP}$; at $2 \sigma, 800-1260 \mathrm{cal} \mathrm{BP}$ ), our best estimate for the age of the anthropomorphic pictograph at the Lewis Canyon site, 41VV233. The propagated uncertainty is that from the various measurements, but does not include possible heterogeneity of background organic material. Because the background is close in age to the pictograph, the background-corrected age is shifted by only $190 \mathrm{yr}$, in spite of the substantial fraction of contamination.

The depiction of bows and arrows broadly constrains the age of Red Monochrome pictographs in the Lower Pecos River region. These weapons were introduced to the area after $c a .1350 \mathrm{BP}$. Turpin (1986a) suggested that the lack of bison images in the paintings indicates the absence of bison in the area during the time of Red Monochrome art. Dillehay's (1974: 181) period III places bison incursion into southwest Texas from “A.D. 1200-1300 to 1550", eliminating this time frame for the Red Monochrome style. Thus, the date of 41VV233-1 falls within the range accepted for the Red Monochrome style ( $c a .650$ to $1350 \mathrm{BP}$ ). The agreement with the archaeological estimate is of limited use for evaluating the efficacy of the plasma-chemical method since it yields a 700-yr time span.

Dissimilarity between this style and the older Pecos River style has led archaeologists to believe that the Red Monochrome painters were newcomers, unrelated to former inhabitants (Kirkland and Newcomb 1967; Turpin 1986a). It may be helpful to compare the age of this Red Monochrome pictograph with archaeologically estimated ages for similar motifs elsewhere. Anthropomorphic figures similar to those shown in Figures 2 and 3 are found in the Four Corners area of Arizona, Colorado, New Mexico and Utah (cf. Schaafsma 1980; Cole 1990). Cole (1990: 133) hypothesizes that representations of "lizard" men may have developed during the Pueblo I period ("AD 700-900"); they then "dominate Pueblo II and III rock art" ("AD 850-1300"). Our age for the Red Monochrome anthropomorph lies in the Pueblo I period, but with the uncertainty overlaps into Pueblo II, suggesting a possible link between the prehistoric Red Monochrome culture of the Lower Pecos River area and the Four Corners Pueblo III populations.

\section{Cueva del Ratón, Baja California, Mexico}

Two samples, one consisting of red pigment (Cueva del Ratón-6) and the other of black pigment (Cueva del Ratón-2), both on a glossy substrate, were brought to us by O. W. Hampton (Department of Anthropology, Texas A\&M University) at the request of the collector, Dr. J. M. Fullola i Pericot (Department of Prehistory, University of Barcelona). The first (-6) gave an AMS age of $1325 \pm 125$ $\mathrm{BP}$ (AA-9234), the second (-2), $295 \pm 115 \mathrm{BP}$. The red pigment was taken from an anthropomorphic figure, with schematized features (Fullola et al. 1994). The background for these samples was collected much later by Mr. Hampton, who said that the rock was the same as that on which both the pictographs were painted. However, the background rock appeared redder to us than the greyish pictograph basal rock. We were not invited to sample either directly. Nonetheless, we broke several small pieces off the surface of the unpainted background sample which we put through our plasma
procedure. Subsequent oxidation yielded $\mathrm{CO}_{2}$ that dated to $3490 \pm 60 \mathrm{BP}$. 
The Cueva del Ratón samples are problematic. Our dates indicate that the background cannot be applicable to both pictographs. Cueva del Ratón-2 had about the same amount of $\mathrm{CO}_{2}$ as did the background rock. If an appreciable fraction of the $\mathrm{CO}_{2}$ in Cueva del Ratón-2 were provided by the background rock we were given, its age would have been much older than $295 \mathrm{BP}$. In spite of the fact that Fullola et al. (1994: 3) reported that the 295 BP age "corresponds to what we intuited as to its modernity" (our translation from Spanish), we have little confidence in this age because of the small amount of organic material dated $(\sim 100 \mu \mathrm{g})$ and the lack of a reliable background for comparison.

Cueva del Ratón-6 produced considerably more $\mathrm{CO}_{2}$ than did Cueva del Ratón-2. Thus, with a reliable background sample, it may be possible to extract a meaningful date as attempted earlier for the Red Linear and Red Monochrome style pictographs from Texas. The difficulty with the Cueva del Ratón samples illustrates the need for close and continuous collaboration between analysts and archaeologists. Ideally, both should be present when collecting samples and backgrounds to avoid wasted time, expense and confusion. For now, we regard our results from Cueva del Ratón with skepticism.

\section{Mucubal 1, Opeleva Cave, Angola, Africa}

Animals and figures painted in black, white and red decorate several Angolan caves. We received a sample of charcoal pigment from Mucubal 1, Opeleva Cave, Angola from Michel Menu (Research Laboratory of the Museum of France, Louvre), collected by Manual Guttierez. The sample, large enough to split in two, was from a black line drawn beneath a "goat". The first aliquot of $12.9 \mathrm{mg}$, including the substrate rock and pigment, was placed in the plasma-chemical chamber and treated routinely. Sufficient gas was released so that we obtained three $\mathrm{CO}_{2}$ portions, two of which were ${ }^{14} \mathrm{C}$-dated. They yielded ages of $1900 \pm 60 \mathrm{BP}$ and $1880 \pm 60 \mathrm{BP}$, showing good reproducibility of the plasma-chemical technique. One of us (J.S.) treated the second aliquot of the original sample for routine archaeological charcoal dating, i.e., subjected it to $\mathrm{NaOH}$ and $\mathrm{HCl}$ washes to remove the humic acids and carbonates. This sample produced a date of $2340 \pm 50 \mathrm{BP}$ : at $1 \mathrm{\sigma}, 2330-2350 \mathrm{cal} \mathrm{BP}$; at $2 \sigma, 2160-2650 \mathrm{cal} \mathrm{BP}$. It is clear from these results that as with all archaeological charcoal dating, it is essential to pretreat charcoal pigments to obtain accurate results. In our case, the $\mathrm{NaOH}$ treatment should be sufficient since carbonates are of no consequence in the plasma-chemical extraction. It is not always clear from the literature whether pictograph charcoal pigments are pretreated before AMS ${ }^{14} \mathrm{C}$ measurement (van der Merwe, Sealy and Yates 1987; McDonald et al. 1990; David 1992; Farrell and Burton 1992; Geib and Fairley 1992). Chaffee et al. (1994a) did not pretreat the charcoal pigment from the All American Man pictograph in Utah. However, a dated underlying layer generally confirmed the charcoal date (see Table 1 ). The charcoal portion dated to $753 \pm 57$ with $575 \pm 68$ BP for the underlying layer. Although the apparent difference was not statistically different (Stuiver and Reimer 1993), the lack of pretreatment and/or the "old wood" problem (Schiffer 1986) may have affected the charcoal date.

\section{ConClusion}

We extracted the organic matter and obtained direct AMS ${ }^{14} \mathrm{C}$ dates from pictographs around the world. The extraction removes organic material, whether from the pictograph or from inherent organic material trapped in the rock or mineral accretions. Dating pictographs containing charcoal pigment is straightforward if sufficient sample is taken to allow for standard pretreatment to remove carbonates, oxalates and humic acids. A sample of Angolan charcoal pigment illustrated that this pretreatment is essential. Our method is limited because, in some cases, 1) either no organic material was added to the paint, or it had decomposed completely since the paint was applied, so that we can- 
not obtain enough carbon from the plasma treatment for dating, and 2) rock and mineral accretions of the painted surfaces contain organic matter (contamination) that affects the pictograph date.

We discussed our treatment of the data in four cases where substantial background contamination occurred: 2 from Texas; 1 from Baja California, Mexico; and 1 from Angola. In other more extreme cases, the level of organic carbon in the unpainted surfaces was so large that it invalidated AMS ${ }^{14} \mathrm{C}$ ages obtained on associated pictographs. Although progress has been made and believable results produced, it is premature to suggest that problems with dating rock art have been solved. For pictographs displaying substantial background, chemical pretreatment may be required to obtain a reliable and accurate result. Yet, in areas that lack ethnographic information, rock art is the primary source for understanding sacred and psychological cultural values of past inhabitants.

\section{ACKNOWLEDGMENTS}

We are grateful to the following for partial support: the Research Corporation Grant R-157; the Donors of the Petroleum Research Fund Grant ACS-PRF 20252-AC8 administered by the American Chemical Society; the Robert A. Welch Foundation Grant A-1235 and the Texas Archaeological Society. Discussions on statistics with Ruth Ann Armitage, David Carlson and Tom Wehrly were helpful. Katherine Riddle, Thomas Bouton, Ethan Grossman and Luis Cifuentes determined $\delta^{13} \mathrm{C}$ values for us. The Spanish translation of the Fullola et al. paper was done by Jack D. Rowe.

\section{REFERENCES}

Chaffee, S. D., Hyman, M. and Rowe, M. W. 1993 AMS ${ }^{14} \mathrm{C}$ dating of rock paintings. In Steinbring, J. and Watchman, A., eds., Time and Space: Dating Considerations in Rock Art Research. Occasional AURA Publication No. 8, Australian Rock Art Research Association: 67-73.

1994a Radiocarbon dating of rock paintings. In Whitley, D. and Loendorf, L. L., eds, New Light on Old Art: Recent Advances in Hunter-Gatherer Rock Art. Institute of Archaeology, Monogram 36, Berkeley/Los Angeles, University of California Press: 9-12. 1994b Vandalism of rock art for enhanced photography. Studies in Conservation 39: 161-168.

Chaffee, S. D., Hyman, M., Rowe, M. W., Coulam, N. J., Schroedl, A. and Hogue, K. 1994a Radiocarbon dates on the All American Man pictograph. American Antiquity 59: 769-781.

Chaffee, S. D., Loendorf, L. L., Hyman, M. and Rowe, M. W. 1994b Dating a pictograph in the Pryor Mountains, Montana. Plains Anthropologist 39: 195-201.

Chandler, S. M. 1990 Limited excavations at Bighorn Sheep Ruin (42SA1563) Canyonlands National Park, Utah. Utah Archeology 3: 85-105.

Clottes, J., Courtin, J. and Valladas, H. 1992 A well dated Palaeolithic cave: The Cosquer Cave at Marseilles. Rock Art Research 9: 122-129.

Cole, S. J. 1990 Legacy on Stone: Rock Art of the Colorado Plateau and Four Corners Region. Boulder, Colorado, Johnson Books: 279 p.

David, B. 1992 An AMS date for Queensland rock art. RockArt Research 9: 139-141.

Dillehay, T. 1974 Late Quaternary bison population changes on the southern plains. Plains Anthropologist 19: 180-196.

Farrell, M. M. and Burton, J. F. 1992 Dating Tom Ketchum: The role of chronometric determinations in rock art analysis. North American Archaeologist 13: 219-247.

Fullola i Pericot, J. M., Petit, M. A., Bergada, M. M., del Castillo, V., Rubio, A., Sarria, E. and Vinas, R. 1994 La datación de los pinturas rupestres. La Vanguardia, Ciencia y Tecnologia 211: 3.

Geib, P. R. and Fairley, H. C. 1992 Radiocarbon dating of Fremont anthropomorphic rock art in Glen Canyon, south-central Utah. Journal of Field Archaeology 19: 155-168.

Greider, T. 1966 Periods in the Pecos style pictographs. American Antiquity 31: 710-720.

Kelley, J. C. 1950 Atlatls, bows and arrows, pictographs, and the Pecos River focus. American Antiquity 1: 7174.

Kirkland, F. and Newcomb, W. W., Jr. 1967 Rock Art of Texas Indians. Austin, University of Texas Press: 239 p.

Loendorf, L. L. 1988 Rock art chronology and the Valley of the Shields site (24CB1094) in Carbon County, Montana. Archaeology in Montana 29: 11-24.

Loy, T. H., Jones, R., Nelson, D. E., Meehan, B., Vogel, J., Southon, J. and Cosgrove, R. 1990 Accelerator radiocarbon dating of human blood proteins in pigments from Late Pleistocene art sites in Australia. Antiquity 64: $110-116$

McDonald, J., Officer, K., Jull, T., Donahue, D., Head, J. and Ford. B. 1990 Investigating ${ }^{14} \mathrm{C}$ AMS: Dating pre- 
historic rock art in the Sydney Sandstone Basin, Australia. Rock Art Research 7: 83-92.

Mook, W. G. and Waterbolk, H. T. 1985 Handbooks for Archaeologists Number 3, Radiocarbon Dating. Strasbourg European Science Foundation: $65 \mathrm{p}$.

Reese, R. L, Derr, J. N., Hyman, M., Rowe, M. W. and Davis, S. K., in press, Ancient DNA in Texas pictographs. Journal of Archaeological Science.

Russ, J., Hyman, M., and Rowe, M. 1992 Direct radiocarbon dating of rock art. In Long, A. and $\mathrm{Kra}, \mathrm{R}$. S., eds., Proceedings of the 14 th International ${ }^{14} \mathrm{C}$ Conference. Radiocarbon 34(3): 867-872.

Russ, J., Hyman, M., Shafer, H. J. and Rowe, M. W. 1990 Radiocarbon dating of prehistoric rock paintings by selective oxidation of organic carbon. Nature 348: 710-711.

$1991{ }^{14} \mathrm{C}$ dating of ancient rock art: A new application of plasma chemistry. Plasma Chemistry and Plasma Processing 11: 515-527.

Schaafsma, P. 1980 Indian Rock Art of the Southwest. Albuquerque, University of New Mexico Press: $379 \mathrm{p}$.

Schiffer, M. B. 1986 Radiocarbon dating and the "old wood" problem: The case of the Hohokam chronology. Journal of Archaeological Science 13: 13-30.

Stuiver, M. and Reimer, P. J. 1993 Extended ${ }^{14} \mathrm{C}$ data base and revised CALIB 3.0 age calibration program. In Stuiver, M., Long, A. and Kra, R. S., eds., Calibration 1993. Radiocarbon 35(1): 215-230.

Turpin, S. A. 1984 The Red Linear style pictographs of the Lower Pecos Region, Texas. Plains Anthropologist 29: 181-197.
Turpin, S. A. 1986a Pictographs of the Red Monochrome style in the Lower Pecos River region, Texas. Bulletin of the Texas Archeological Society 55: 123-144.

1986b Toward a definition of a pictograph style: The Lower Pecos Bold Line Geometric. Plains Anthropologist 31: 153-161.

1990 Speculations on the age and origin of the $\mathrm{Pe}$ cos River style, southwest Texas. In Turpin, S. A., ed., American Indian Rock Art 16. Austin, University of Texas Press: 99-122.

Valastro, S., Jr., Davis, E. M. and Varela, A. G. 1977 University of Texas at Austin radiocarbon dates XI. Radiocarbon 19(2): 280-325.

Valladas, H., Cachier, H. and Arnold, M. 1990 AMS C14 dates for the prehistoric Cougnac cave paintings and related bone remains. Rock Art Research 7: 1819.

Valladas, H., Cachier, H., Maurice, P., Bernaldo de Quiros, F., Clottes, J., Valdes, V. C., Uzquiano, P. and Arnold, M. 1992 Direct radiocarbon dates for the prehistoric paintings at the Altimira, El Castillo and Niaux Caves. Nature 357: 68-70.

van der Merwe, N. J., Sealy, J. and Yates, R. 1987 First accelerator carbon-14 date for pigment from a rock painting. South African Journal of Science 83: 56-57.

Watchman, A. 1993 Evidence of a 25,000-year-old pictograph in Northern Australia. Geoarchaeology 8: 465-467.

Watchman, A. and Cole, N. 1993 Accelerator radiocarbon dating of plant-fibre binders in rock paintings from northeastern Australia. Antiquity 67: 355-358. 